\title{
Global Warming is an Energy Conundrum
}

\author{
Jan-Erik Lane ${ }^{1}$ \\ ${ }^{1}$ Fellow with Public Policy Institute, Myanmar \\ Correspondence: Jan-Erik Lane, Fellow with Public Policy Institute, BELGRADE; Address: 10 Charles \\ Humbert, 1205 Geneva; 559 A, 3rd Floor, Thuya Street, 9th Quarter, Yangon. Myanmar. E-mail: \\ janeklane@gmail.com
}

Received: January 8, 2018

Accepted: January 18, 2018

Online Published: March 15, 2018

doi:10.5539/esr.v7n2p1

URL: https://doi.org/10.5539/esr.v7n2p1

\begin{abstract}
Climate change is at its core an energy problematic. The main anthropogenic source of greenhouse gases is energy consumption. It is vital, because it makes affluence and wealth feasible. Energy demand is projected to double by 2050 at the same time as governments have obliged themselves to drastic decarbonisation. The risk is obvious that energy demand trumps emission reduction.
\end{abstract}

Keywords: GHG, CO2, energy, decarbonisation, COP21 defection

\section{Introduction}

Why is there little headway for the COP21 project? It is now less than 2 years to the start of the huge global decarbonisation project that governments have committed their states to accomplish during the next fifty years. But the emissions of greenhouse gases are still augmenting got the entire Planet Earth, despite many small scale promising initiatives with innovations and experiments. The reason that the COP2 1 looks more and more as an example of coordination failure id that behind the emission of $\mathrm{CO} 2 \mathrm{~s}$ there is the energy pyoblem that is essential to al socio-economic development in general and economic growth in particular. Decarbonisation requires deep cuts in the use of fossil fuels, furnishing vital energy for humans and social systems, but the governments of the world plan for large energy increases in the future to meet the expectations of markets and households. Governments may assent to decarbonisation goals, but they do not really plan effectively for it, at least not the big emitters of $\mathrm{CO} 2$, the $\mathrm{G} 20$ group of nations.

Figure 1 shows the connection between GDP and energy for the last nearly 30 years. Energy comes in in every sector in the economy and living standards cannot be raised without some form of energy.

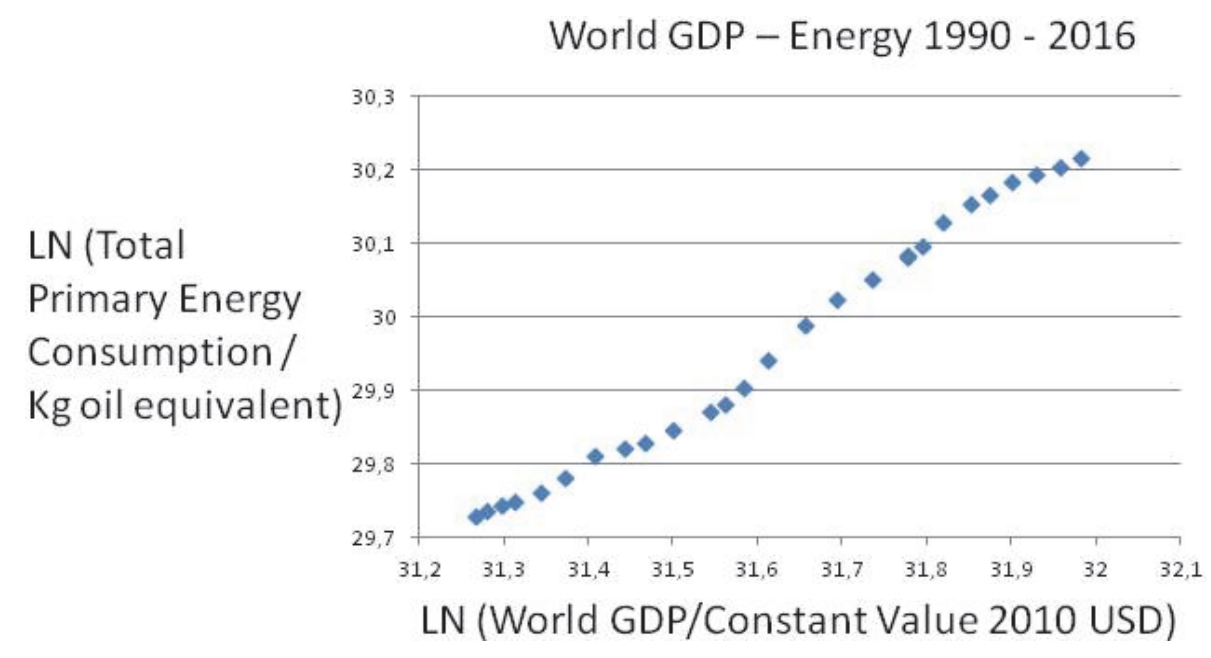

Figure 1. GDP and energy 1990-2016

The enormous increase in energy is set o continue in the $21^{\text {st }}$ century, as almost all governments aim for economic growth. What then about the decarbonisation plans? 
The connection between GHG emissions and energy is by now well researched, with the overwhelming evidence pointing at the anthropogenic sources of GHG emissions, i.e. mainly energy consumption in a wide sense. The countries of the world have promised large scale decarbonisation but they plan for increased energy consumption. How is the Gordian knot to be untightened? Perhaps simply by defection? The purpose of this paper is to discuss this ebergy conundrum in relation to a few of the really big emitters among the G20 group of nations? Are their plans in agreement with he goals of global decarbonisation?

\section{Decarbonisation and the G20 Group of Nations}

Now, the countries in the world have formed a common pool regime (CPR) to save the atmosphere from more GHGs, focusing only upon the CO2s. The global decarbonisation plan in the COP21 Treaty includes:

i) Stall the rise if CO2s by 2020 (GOAL I);

ii) Decreasing the CO2s by $30-40 \%$ by 2030 (GOAL II);

iii) More or less full decarbonisation by around 2075 (GOAL III);

iv) Decentralised implementation under international oversight, financial support and technical assistance.

These are enormous goals, as only one country - Uruguay - is near GOAL I and GOAL II. Can they be implemented? Will the G20 group of nations implement them or will they renege in this giant ocean PD game (Prisoner's dilemma)? Only Japan has decreasing $\mathrm{CO} 2$ curves today among vibrant Asian economies.

Global decarbonisation is handled by the UN and a few of its bodies, especially the UNFCCC. It has one meeting a year, characterized by transaction costs. Global warming is mixed with other issues in large scale reunions with over 190 governments. Thus, e.g. funding of decarbonisation is a major issue, as the COP21 has promised 100 billion $\$$ each year for some 10 years. But who is to pay? Third World countries claim that the early industrialisers must take the major bueden, as "they caused the problem". Re-distributional justice is often referred to and utopian solutions of global sustainability are debated.

Yet, the key decision-makers are the G20 nations, because they are responsible for over 70 per cent of all GHGs. Emissions go with enrgy consumption. Figure 2 shows the dominant role of G20 nations in global energy.

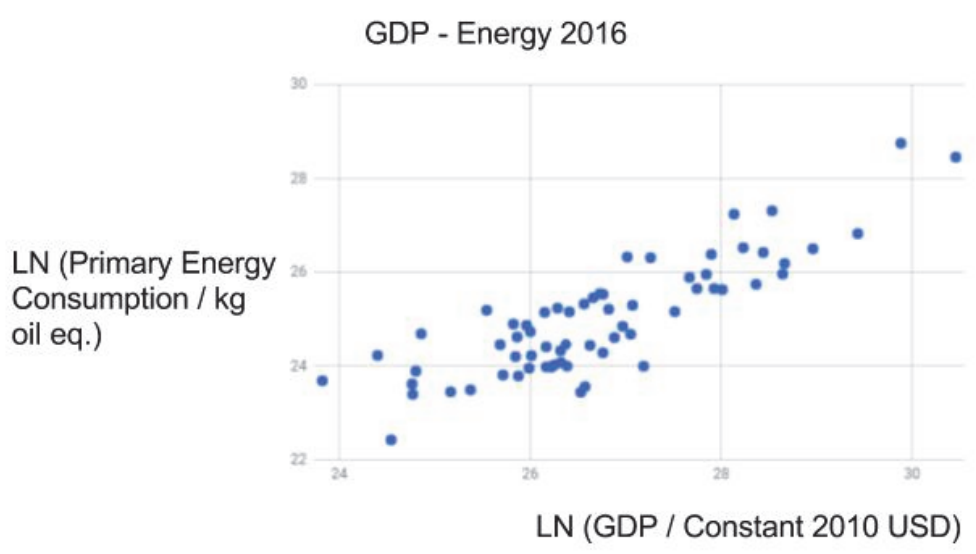

Figure 2. Energy consumption in countries by GDP 2016

The energy plans for the future of the 21st century among G20 nations decides whether the COP21 project will result in coordination success or failure. Global decarbonisation along the COP21 Treaty requires the G20 nations to pursue energy policies like these:
a) Close down all coal plants;
b) Cut back oil consumption in favour of natural gas;
c) Reduce also natural gas demand in favour of bioenergy;
d) Build massively solar and wind power plans;
e) Retain and upgrade nuclear power plants;
f) Build new atomic plants with new technology;
g) Stop all forms of deforestation. 
When one consults the stylized energy projections by the EIA, IEA and BO energy outlooks, one find little impact of the promised implementation of global decarbonisation, Consider Figure 3.

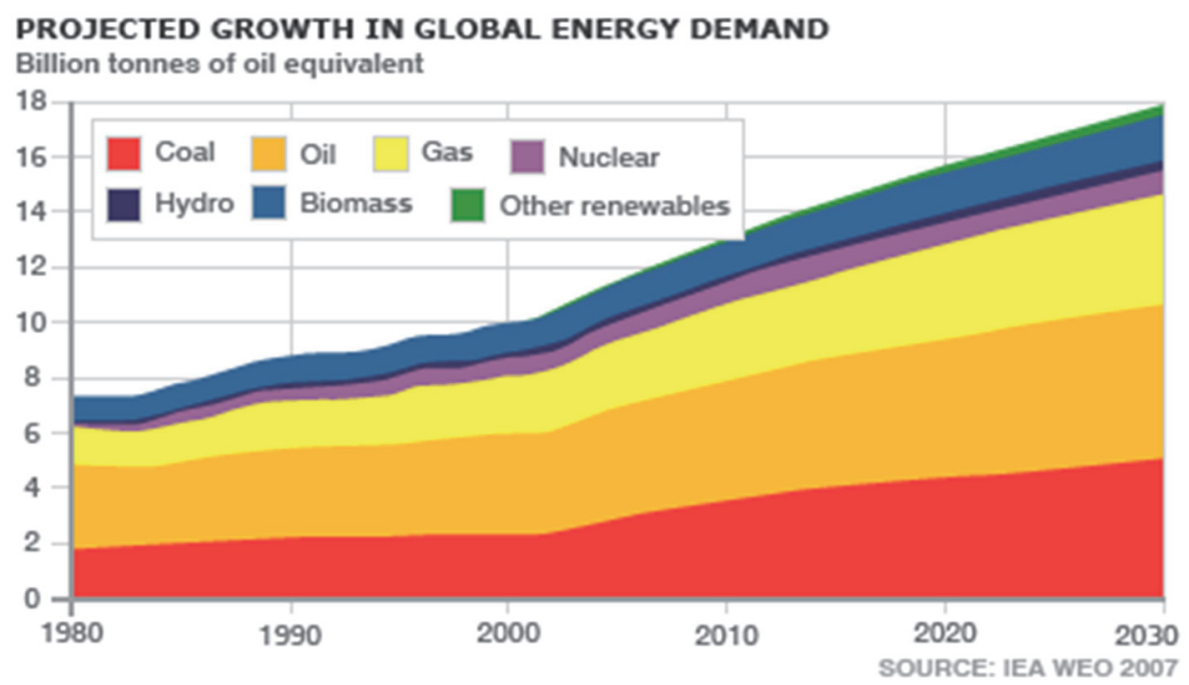

Figure 3. Global energy demand, projections

Source: http://news.bbc.co.uk/2/hi/science/nature/7081679.stm

\section{Defection Risks of Cop21}

\section{China: $20 \%$ more energy up to 2030}

China has expressed support for COP21, especially when smog hits Beijing. But its economic expansion endeavours remain unchanged, not least over Asia with the New Silk Road. Alarming information now arrives that China, the biggest emitter of $\mathrm{CO} 2 \mathrm{~s}$, will not succeed to halt its curve for $\mathrm{CO} 2 \mathrm{~s}$ due to hydro power shortages Instead, it counts upon some 3 per cent increases the nearest 1-2 years - see Figure 4.

GDP - CO2 Emissions for China 1990 - 2016

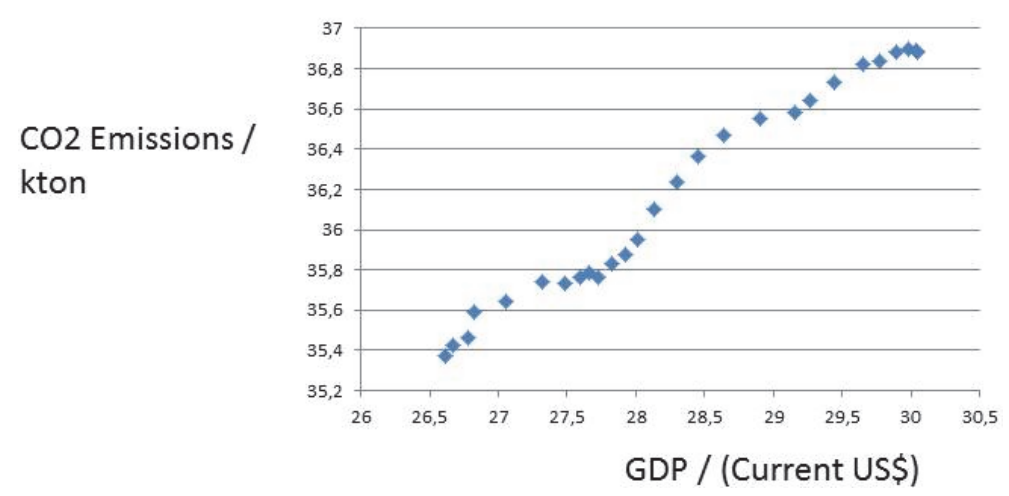

Figure 4. China: GDP and CO2s: $y=0,46 x, R^{2}=0,98$

Will China renege upon both GOAL I, halting the increase in CO2s, and GOAL II, reducing CO2s by some 30 per cent in 10 years? Promises and intensions are one thing, defect, but real life developments are another matter. All countries in this CPR can at any time renege, the US has already done being not willing to pay to the Super Fund.

China invests in both nuclear power and modern renewables. Yet, it has magnificent economic ambitions over the next decades:

i) Airports and own constructed aircraft;

ii) Largest air traffic in the world;

iii) Biggest car market in the world' 
iv) More SUVs and ever larger engines;

v) The New Silk Road: infra structure expansion into Central Asia, Pakistan and the Middle East.

Air and sea transportation adds much to $\mathrm{CO} 2$ emissions. Even if electrical cars are launched massively in China, one must ask where the electricity comes from. Coal?

China expanding outward meets first Kazakhstan when building the new highway to Turkey, an enormous project with $\mathrm{CO} 2$ consequences.

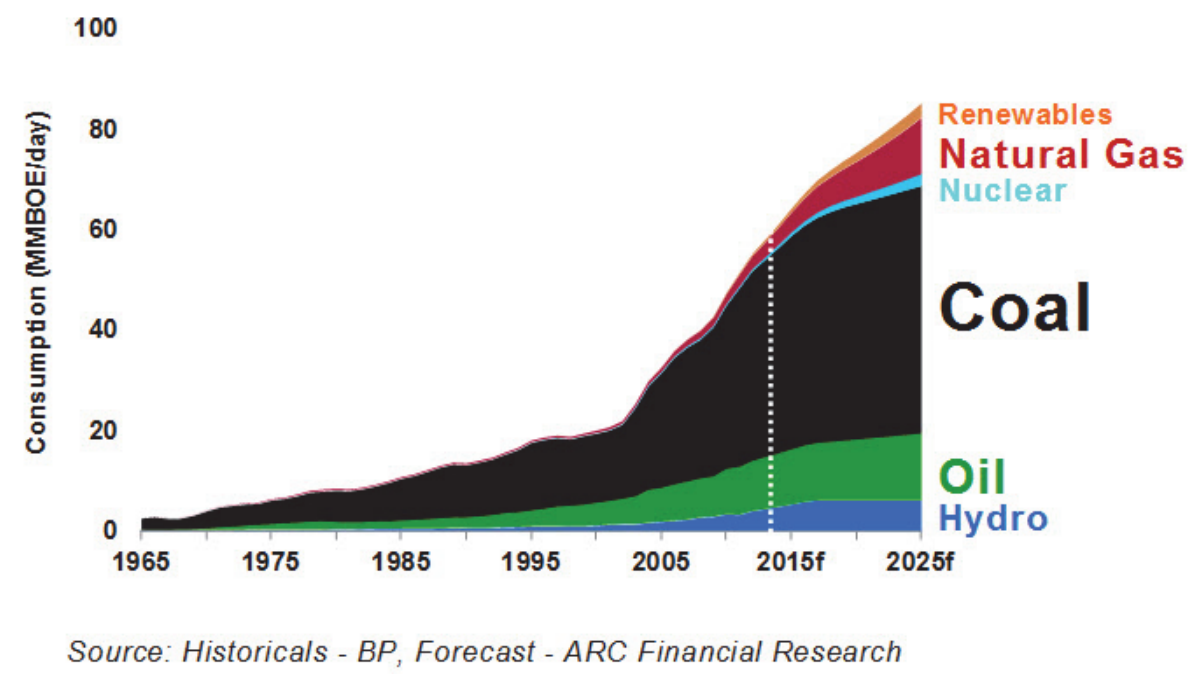

Figure 5. China's future energy mix

Source: China energy consumption by type 1965 to $2015 f$

Figure 5 send a vision of a future that is not the same as that of the COP21 project.

\section{Kazakhstan: Oil and gas}

Here, we have a nation very much occupied with the catch-up strategy, as its exit from the Soviet Union worked like a "take-off" stage. It wants to copy the Asian miracles, moving to affluence in a few decades, using its immense fossil energy resources (Figure 6). But this picture of over $90 \%$ fossil fuels is very far from the obligations under the COP21 Treaty.

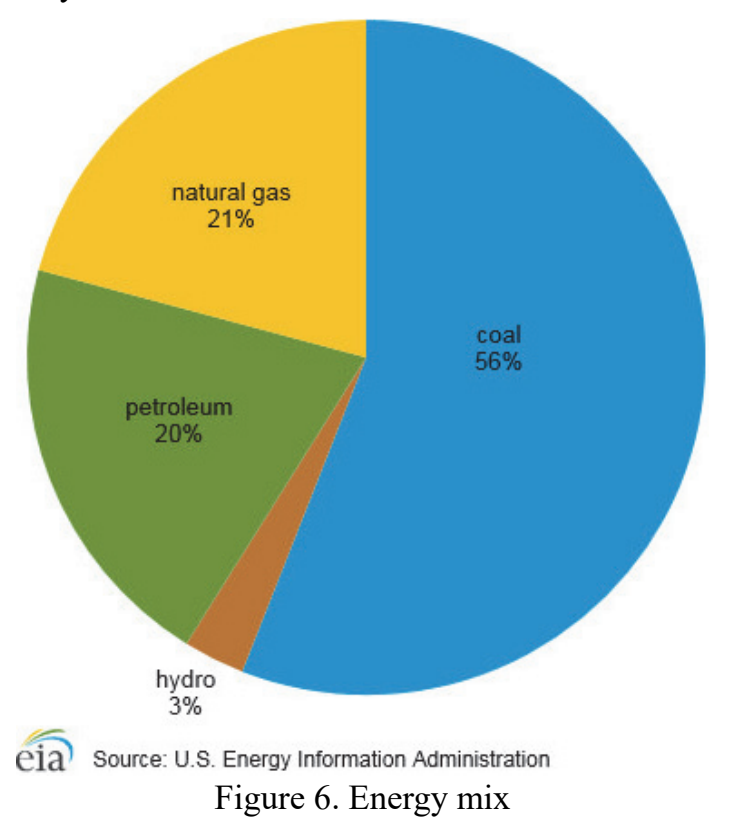

Source: Kazakhstan energy consumption by fuel, 2014 
Kazakhstan's energy consumption leads to enormous emissions. The stunning economic development, including the great project of a modern Silk Roan from China to Turkey through Kazakhstan implies that the CO21 goals cannot be accomplished here. Catch-up strategy and huge infrastructure trump climate change. Countries with no hydro power often display increasing trends for emissions. Kazahkstan employs its vast fossil fuel resources for energy consumpton besides exporting a lot. But it has to start energy transformation towards renewables

\section{Turkey: Imported energy}

Turkey has never been politically stable, neither today nor historically speaking. The Ottoman Empire was an example of oriental despotism, namely sultanismus. When the Young Turks set up modern Turkey, they failed to stabilize the country with a permanent constitution. The many constitutional changes reflect not only coup d'état, but also a weak tradition of the Rechtsstaat. Economically, things are entirely different, as Turkey is one of giants of the global economy, especially important with connections to the West and dominance in Turkestan.

Comparing the picture for Turkey with that of "catch-up" nations, one may state that Turkey has the typical GDP-GHG link, despite lots of hydro power. Strong economic development is combined with heavy emissions increase. Since the world organisations - the UN, WB and IMF - opt for more of economic growth, one must ask whether emissions growth really can be halted. Figure 7 supports this picture of Turkey as an energy consuming giant.

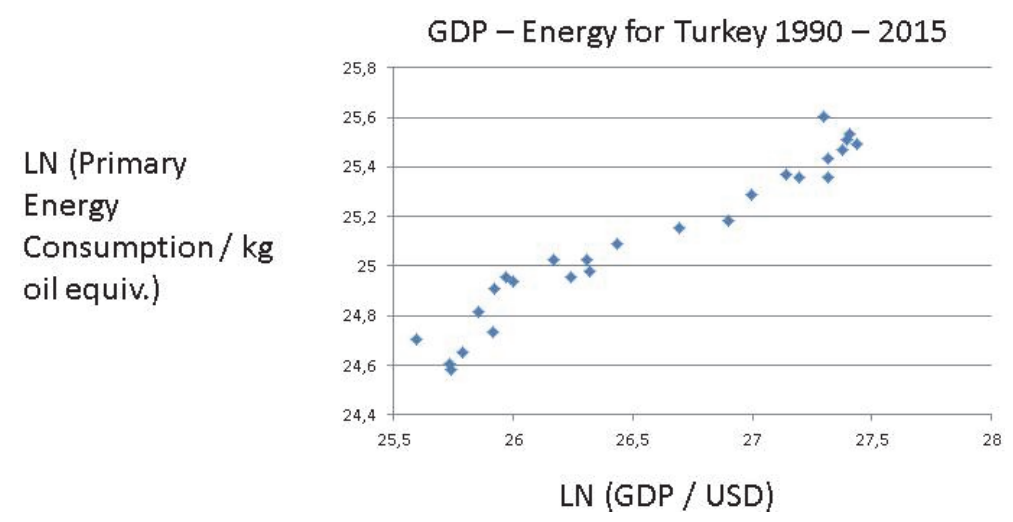

Figure 7. Turkey: energy-GDP link

Strong economic development is combined with heavy energy-emissions increase. Oil and gas are imported from the East. Only hydro power is a large internal source of energy. Wind energy has become fashionable, but solar energy would be an ideal solution. Figure 8 displays the still heavy reliance of Turkey on fossil fuels, mostly imported. Decarbonisation according to the COP21 Treaty implies that Turkey must change drastically, as it now depend at $90 \%$ on fossil fuels.

\section{Primary Energy Consumption of Turkey}

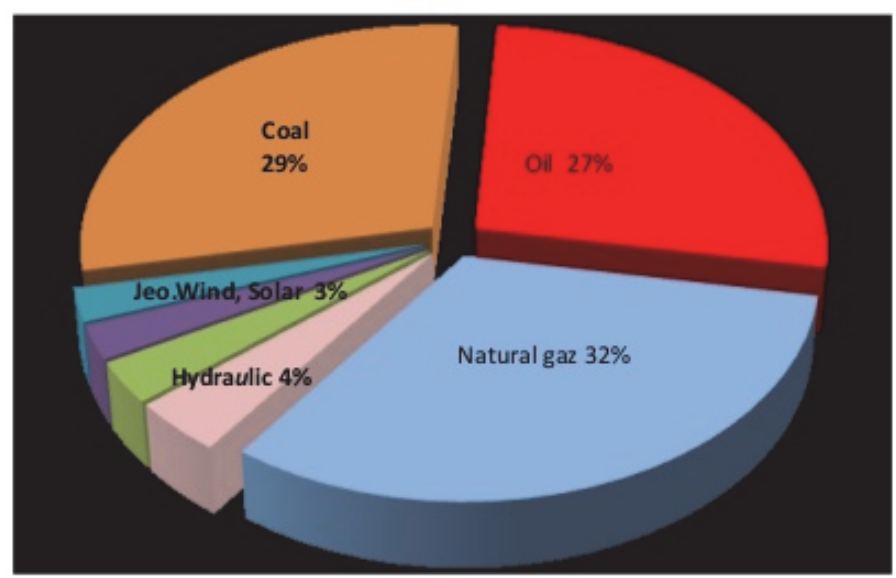

Figure 8. Energy mix in Turkey 
Source: https://www.slideshare.net/omerfarukgurses/world-energy-outlook-2015-presentation

Turkey, Iran and Kazakhstan pursue the "catch-up" strategy in relation to the advanced capitalist countries (Barro, 1991, Barro and Sala-i-Martin, 1992, 1995). They are not very eagre to take on the burden for global decarbonisation, especially if it hurts their economic development. They would demand compensation from the promised Super Fund, as Turkey has now threatened to regene upon its COP21 promises.

\section{Iran: Need of Solar Power}

Countries may rely upon petroleum and gas mainly - see Iran. CO2 emissions have generally followed economic development in the giant carbon rich countries. In Iran though, there seems to be a planning out recently, perhaps due to the international sanctions against its economy. Iran has made considerable economic advances, despite international sanctions, but it's $\mathrm{CO}$ :s has also increased much (Figure 9).

GDP vs. CO2 emissions Iran 1990-2014

LN

(CO2 emissions

$/ \mathrm{kg}$ )

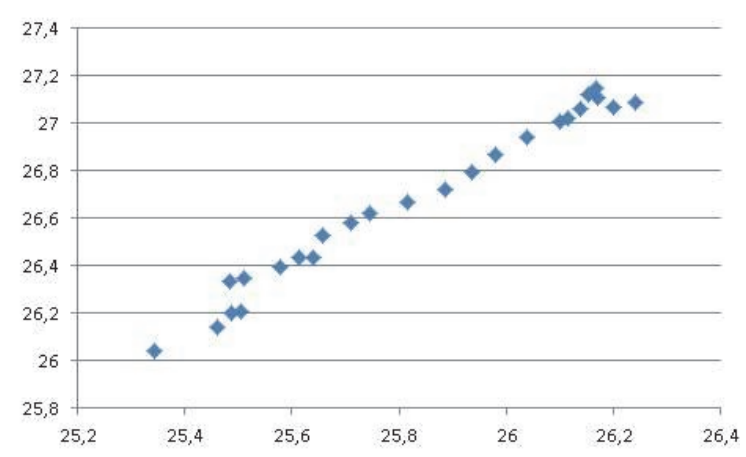

LN (GDP / (Constant Value 2005 USD))

Figure 9. Iran: GDP-CO2 link $\left(y=1,22 x-4,91 ; \mathrm{R}^{2}=0,98\right)$

Iran is together with Russia and Qatar the largest owner of natural gas deposits, but also Turkmenistan and Uzbekistan have enormous gas reserves. But despite using coal in very small amounts, its $\mathrm{CO} 2$ emissions are high. Natural gas pollute less than oil and coal, but if released unburned it is very dangerous as a greenhouse gas. Iran relies upon its enormous resources of gas and oil (Figure 10) to support the "take-off" of its economy (Rostow, 1960).

\section{Iran's total primary energy consumption, share by fuel 2013}

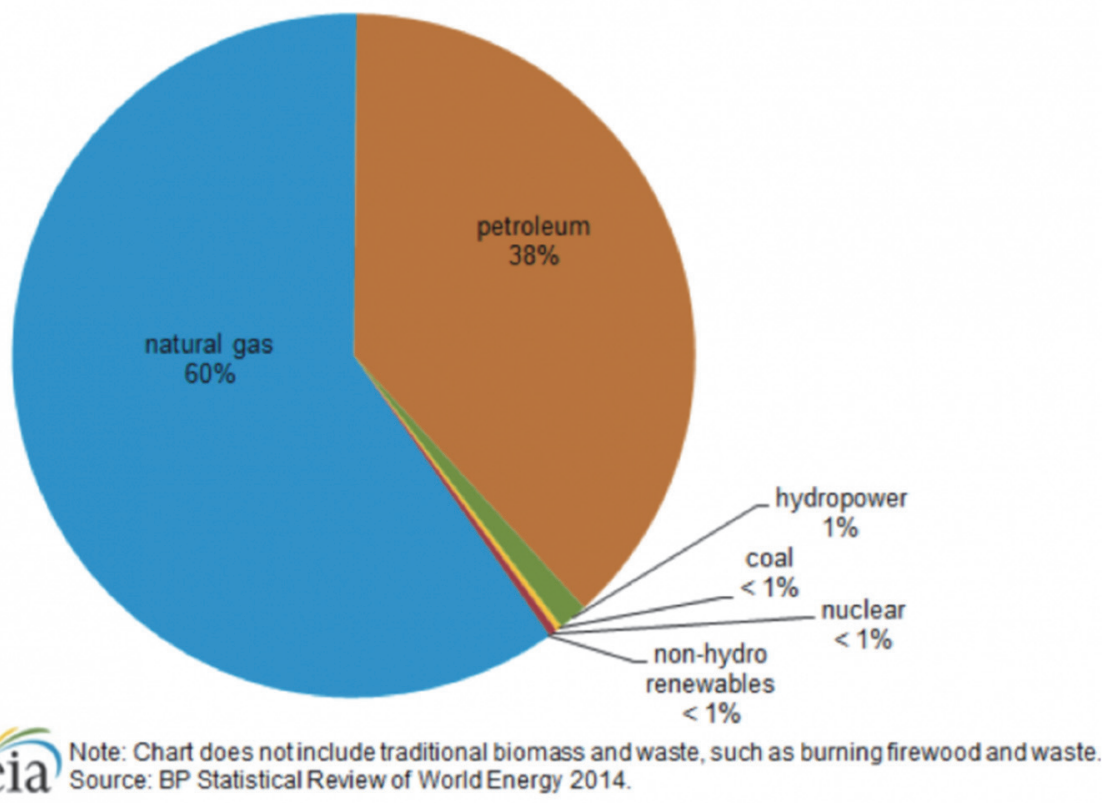

Figure 10. Iran: Energy Mix 
Iran is far from the goals of the COP21 Treaty, relying to 95\% upon fossil fuels. It face difficulties with all three major objectives of the UNFCCC: GOAL I, II and III. Iran needs foreign exchange to pay for all its imports of goods and services. Using nuclear power at home and exporting more oil and gas would no doubt be profitable for the country. And it would also help Iran with the COP21 goals achievement. Solar power parks are the best solution.

\section{India: Super Fund Hope}

Its Rostov take-off point in time would 1990, when Nehru's economic regime was abandoned for free market economics. Unleashing the dormant giant of India has led to enormous economic expansion and growth in Co2s - see Figure 11.

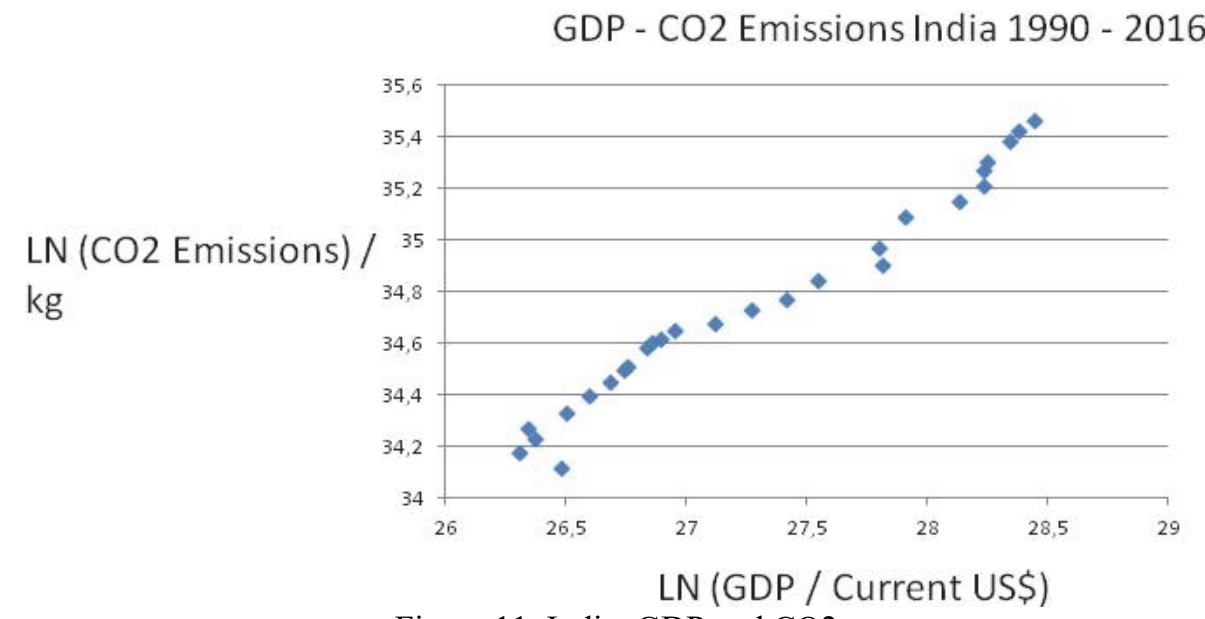

Figure 11. India: GDP and $\mathrm{CO} 2$

India takes the position that any reduction its economic growth due to the fulfillment of global decarbonisation must be compensated by the West. Moreover, the Super Fund should be employed for the energy transformation that is necessary for India to comply with GOAL I and GOAL 2.

Ramesh (2015) insists that India cannot alone uplift its million poor without coal power. In addition, families in India rely much upon wood and charcoal - traditional renewables. The country is investing in nuclear power and modern renewables. However, its hydro power suffers from water scarcity - a positive feedback loop from climate change.

\section{India's changing energy mix}

India is moving towards a robust energy mix, focusing on sustainable energy sources such as solar and wind. By the end of 2026-27, India is projected to get $56 \%$ of its installed power capacity from clean energy sources.

India's total installed power capacity

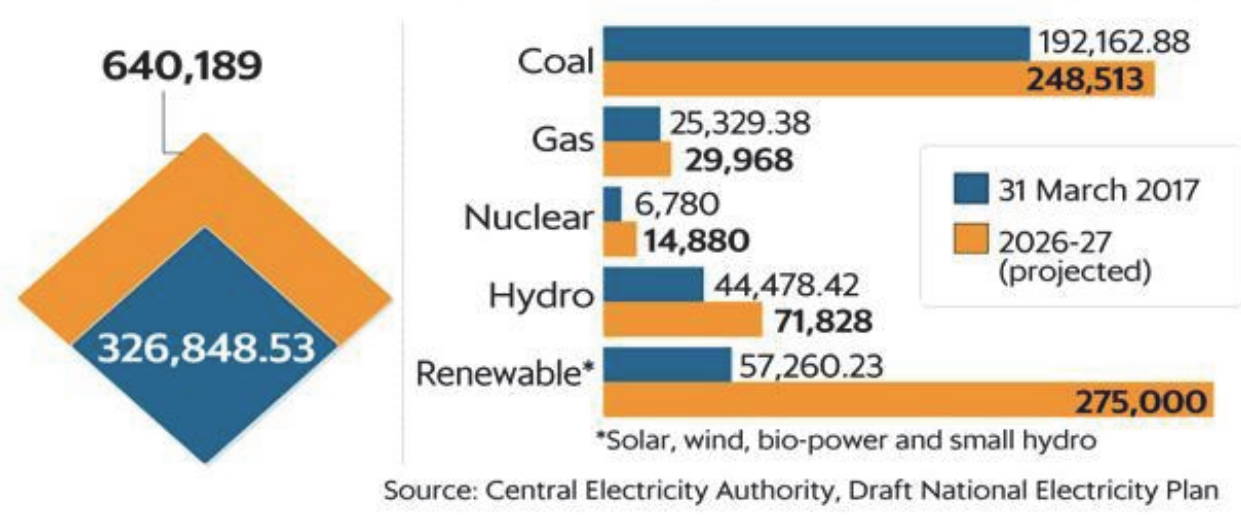

Figure 12. India's planned energy mix (Excluding transport) 
India says that it will renege, if no massive support from the Super Fund. Its future plans, according to Figure 12, comprise a $20 \%$ energy increase. And it must reduce coal more to comply with COP 21 . Renewables in India consist of much wood coal.

\section{South Korea: From Nuclear to LNG}

South Korea is today a member of the club of First Advanced economies, the OECD. From dismal poverty, it has pursued a spectacularly successful catch-up strategy, making it a global leader in technology and car production. The transformation is all the remarkable, as the country possess few internal power resources. Thus, it has relied upon imported fossil fuels, with the result in Figure 15, huge $\mathrm{CO} 2$ emissions.

\section{GDP - CO2 Emissions South Korea 1990 - 2016}
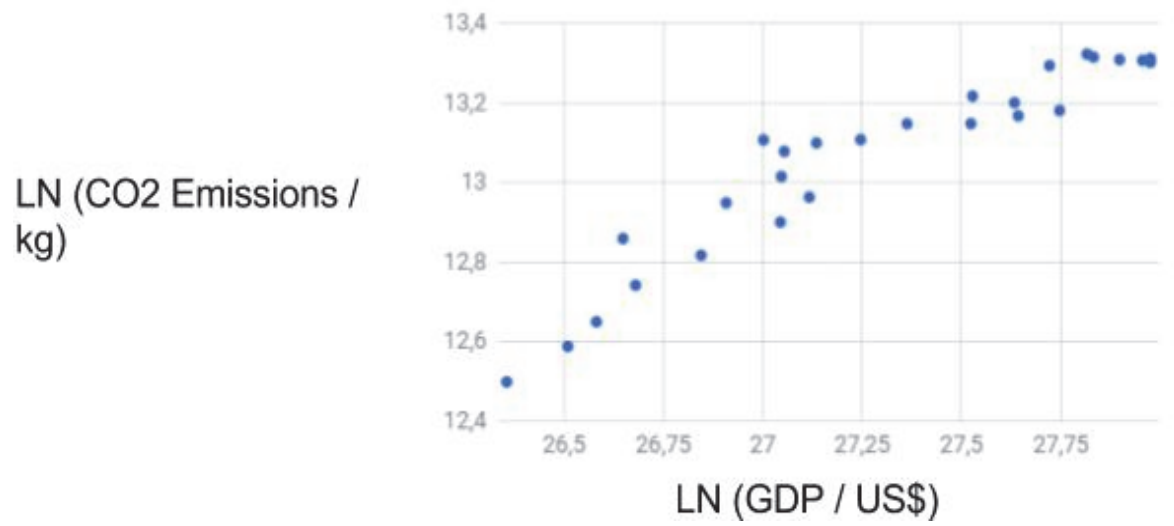

Figure 15. South Korea

To come to grips with its enormous GHG emissions, South Korea has attempted to reduce its coal dependency. Thus, it engaged upon a most ambition nuclear program, as its force is the largest power source in the world. South Korea with its advanced technology can build new and better as well as safer atomic power plants, also constructing them abroad. But the new president hesitates about nuclear power, like the European governments, and has launched a new energy strategy based massively upon natural gas (LNG), imported mainly from Australia and Indonesia. But it will still result in $\mathrm{CO} 2$ emissions higher than GOAL II in CO21. And international maritime transportation is a major source of $\mathrm{CO} 2 \mathrm{~s}$. The LNG option may also appear attractive to Japan, hesitant about the use of atomic power

\section{Evolving Methane Threat}

There are several greenhouse gases, but the two biggest are the $\mathrm{CO} 2 \mathrm{~s}$ and methane. The UNFCCC has concentrated upon halting and reducing carbon dioxide, but now we are about to face a methane threat. We shall use the methane concentration curve from mid-2013 to beginning of 2017 by NOAA ESRL (https://www.esrl.noaa.gov/gmd/ccgg/trends_ch4/), as suggested by Dlugokencky and Kuniyuki. Why mid 2013? It is the last maximum of the second derivative before 2017. Since then, the curve is approximately linear, and we will derive its equation hereunder.

We start with a linear approximation, the simplest approximation that can be found, because it is a mean between two extreme scenarios: 1) Another plateau like during the years 1999-2006 (probably due to an enhancement in methane transport insulation in ex-USSR after 1991, Pearce), unlikely for the following reasons. 2) Any decrease in methane concentration is very unlikely; as the main sources (in decreasing importance order) generally increase:

a) Agriculture emissions increase with the increase of population, the increase in meat diet in developing countries and the temperature increasing the metabolism of microbes in rice agriculture.

b) Wetlands emissions do not diminish, as the microbial chemical activity will increase with temperature for many years.

c) Fossil fuel production and use does not diminish, and was underestimated by industry (Fred Pearce, http://e360.yale.edu/features/methane_riddle_what_is_causing_the_rise_in_emissions).

d) Biomass burning does not diminish, as the primary forest diminishes in the tropics, leading also to a decrease in animal, vegetal and cultural (Indigenous People) diversities and an increase in biosphere entropy.

e) Other natural emissions, like from the melting permafrost. 
The most important contribution to the recent rise of methane concentration is mainly due to the increase in activity by microbes, present in points a), b) and d) mainly in the tropics. This study suggests the positive feedback of the chemical increase of activity of microbes is starting now, yielding a quasi-exponential curve in the near future, or at least a steeper curve.

We will simulate the hypothetical solution of a transition (bifurcation) between 2 steady-states; with an S-shaped function (which approximates the bifurcation between 2 steady-states) multiplied (to have continuity) by the linear approximation. We shall approximate the S-shape curve by a transitory ( 5 years) exponential curve in continuity with the linear approximation. The present (November 2017) quasi-linear curve starts mid 2013 (2013.5) and its ordinate is approximately $1813 \mathrm{ppb}$. We will use as a last value at start of 2017 (2017), and the function is approximately $1846 \mathrm{ppb}$. a straightforward calculation gives the slope: it is approximately $10 \mathrm{ppb} / \mathrm{year}$ $($ Diagram1)/

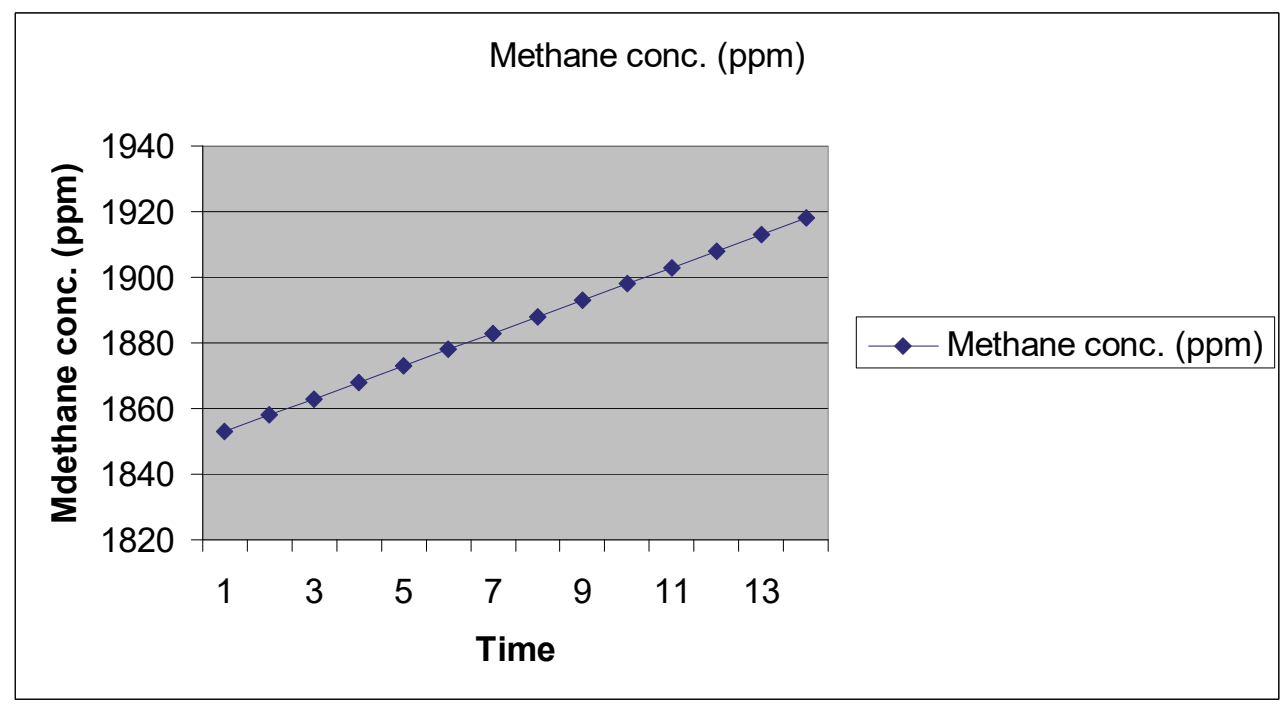

Diagram 1. Projected increase in methane (Dieterlen)

\section{Management Strategies for Decarbonisation}

The UNFCCC suggests a decentralized management strategy for decarbonisation. Reflecting the enormous differences in available energy resources in the member states of COP21 Treaty, each government must develop a strategy for achieving Goal I, Goal II and Goal III. The COP 24 in Poland 2018 may wish to concentrate upon the following measures start credible decarbonisation:

1) Phasing out coal power plants; convincing a few countries like India and Australia not to build new ones;

2) Replace wood coal with natural gas - small or large scale, stopping deforestation and the use of charcoal in households in poor nations, giving them free small gas ovens;

3) Turn some countries away from massive dam constructions towards solar power parks, like Brazil and India, as the environmental damages are too big;

4) Help some countries maintain their huge forests: Brazil, Indonesia, Malaysia, Russia, Congo, India, etc;

5) Abstain from expensive and unsafe carbon sequestration techniques in favour of electricity: solar power and electrical vehicles.

6) The promise of financial support - Super Fund -has to be clarified about both funding and budgeting. A management structure has to be introduced for oversight of the entire decarbonisation process. As the emission of methane increases, the reduction of $\mathrm{CO} 2 \mathrm{~s}$ is all the more important, if irreversibility is to be avoided with a margin.

7) The resort to atomic power plants is highly contested. Nuclear power gets safer and safer, but the problem of storing the used uranium has no solution yet, although Finland says it knows how. Old atomic plants could be made much safer in France and Germany for instance. Full scale climate change would be worse than single nuclear disasters. 
8) Massive construction of solar power and wind power plants in all countries, as well as stimulate small scale solar power; Solar power parks: How many would be needed to replace the energy cut in fossil fuels and maintain the same energy amount, for a few selected countries with big $\mathrm{CO} 2$ emissions? Table 1 has the answer.

Table 1. Number of Ouarzazate plants necessary in 2030 for COP21's GOAL II: (Note: Average of 250 - 300 days of sunshine used for all entries except Australia, Indonesia, and Mexico, where 300 - 350 was used).

\begin{tabular}{|c|c|c|c|}
\hline 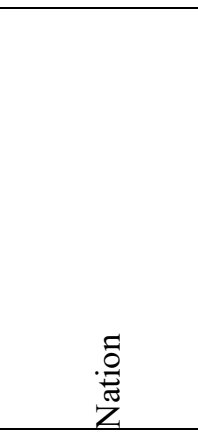 & 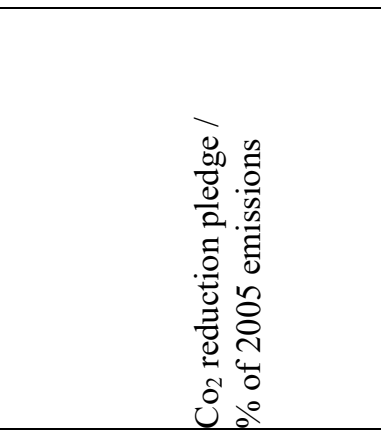 & 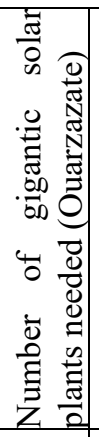 & 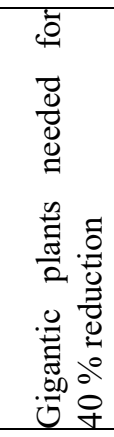 \\
\hline China & None( No absolute target) & 0 & 3300 \\
\hline India & none $^{\mathrm{ii}}$ & 0 & 600 \\
\hline Japan & 26 & 460 & 700 \\
\hline South Korea & 37 & 260 & 280 \\
\hline Philippines & 70 & 70 & 40 \\
\hline Turkey & 21 & 60 & 120 \\
\hline Indonesia & 29 & 120 & 170 \\
\hline Saudi Arabia & none $^{\mathrm{ii}}$ & 0 & 150 \\
\hline Iran & $4-12^{\mathrm{iv}}$ & 22 & 220 \\
\hline Kazakhstan & none $^{\mathrm{ii}}$ & 0 & 100 \\
\hline Turkey & 21 & 60 & 120 \\
\hline Thailand & $20-25^{\text {iv }}$ & 50 & 110 \\
\hline Malaysia & none $\mathrm{i}^{\mathrm{ii}}$ & 0 & 80 \\
\hline Pakistan & none $^{\mathrm{ii}}$ & 0 & 60 \\
\hline Bangladesh & 3,45 & 2 & 18 \\
\hline Australia & $26-28$ & 130 & 190 \\
\hline World & N/A & N/A & 16000 \\
\hline
\end{tabular}

Notes: i) The United States has pulled out of the deal; ii) No absolute target; iii) Pledge is above current level, no reduction; iv) Upper limit dependent on receiving financial support; v) EU joint pledge of $40 \%$ compared to 1990.

\section{Climate Change and Chaos Theory}

The most recent news about the severe negative impacts of global warming is an article in Science saying 1/4ths of the oceans have become oxygen empty - deoxygenation killing fishing and local people livelihood. Can the chaos approach help analysis these drastic changes and their consequences?

Chaos was reinvented in the 1960s by E. Lorenz, who was studying equations ("differential equations") applied to climate. He found a system of three such equations, coupled with a positive feedback and a negative feedback, which could not be predicted in the future (Gleick, 1987).

When trying to predict the evolution, two starting conditions very close one to each other will have two very different evolutions. Even if the two initial conditions are infinitesimally close! That's why the "butterfly effect" started to be cited: if a small (infinitesimally) variation of weather (the "wind" produced by a butterfly) would imply a big variation in the weather far from there. In fact, this is wrong, because the Lorenz equations are too simple for climate, and are simply wrong for climate.

So chaos equations are useless to predict, even if climate is chaotic. But - eliminate this!!!

There are other coupled differential equations, which can help predict things in climate. They are simpler mathematically than chaos, but they have also at least a positive feedback and a negative feedback. 
How do they predict? They are unstable for certain conditions (for example for methane above a given concentration), and we can calculate this instability. Therefore, we can know when the system (climate) will jump from one state to another. Practically, it can be: Earth temperature jumps form 17 degrees in 5 years to 20 degrees in 6 years. The positive feedback is necessary for the system to jump, and the negative feedback is necessary for the system to be stable when it doesn't jump.

The climatic system (a few climatic variables, as temperature, $\mathrm{CO} 2$ and methane concentrations, and maybe one or two other variables) is modelled thanks to a method that transforms chronological data (e.g. monthly data) into those equations.

A stability analysis on a parameter (methane concentration, if we did not put methane as a variable but as a parameter), would see when the system gets unstable., if it does. Without methane, it did not become unstable, but with methane, it likely becomes unstable.

One can show the system as arrows between the variables: each arrow showing if variable A increases or decreases, this affects variable B. This gives an image which shows how the system works, out from the equations directly, and out of the historical data also. One can be sure that the release of massive methane from the melting permafrost will force the Keeling curve upwards, perhaps with a chaotic jump. This may herald Hawking irreversibility.

The threat of a rise in methane emissions due to the melting of the permafrost must be related to the rising Keeling curve. All evidence points to a further advance in Diagram 2: rising CO2s, the many positive feedback lopes, deoxygenation, melting ice, etc.

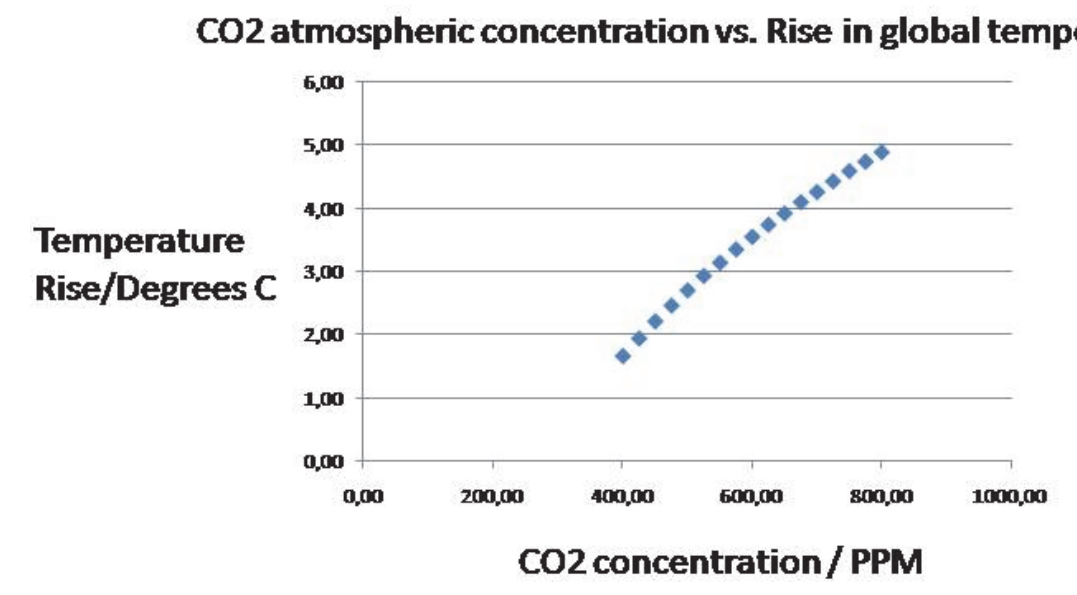

Diagram 2. The Keeling curve

Today, the Keeling curve stands at almost 408, but it could soon hit 420-30, which would make the plus 2 degrees objective unfeasible already before the implementation of COP21 begins.

\section{Conclusion}

Conca (2015) and Vogler (2016) have shown in inquiries into how he UN has handled the climate change that the Great Powers use the fragmented UN structure to delay real action against global warming. They move the key issue of global warming and decarbonisation around, from arena to arena, just to delay concrete measures. The question of climate change is mixed with general environmental protection or the idea of a new sustainable economy, often utopian proposals.

Examining energy consumptions prediction, one observes that energy is expected double. There will renewable energy for sure, but there is no global decarbonisation predicted. Figure 16 shows that the new energy demand will be satisfied by renewables, but the old carbonization structure of energy consumption wil remain. 
World Primary Energy Consumption

(Million Tons of Oil Equivalent, 1950-2050)

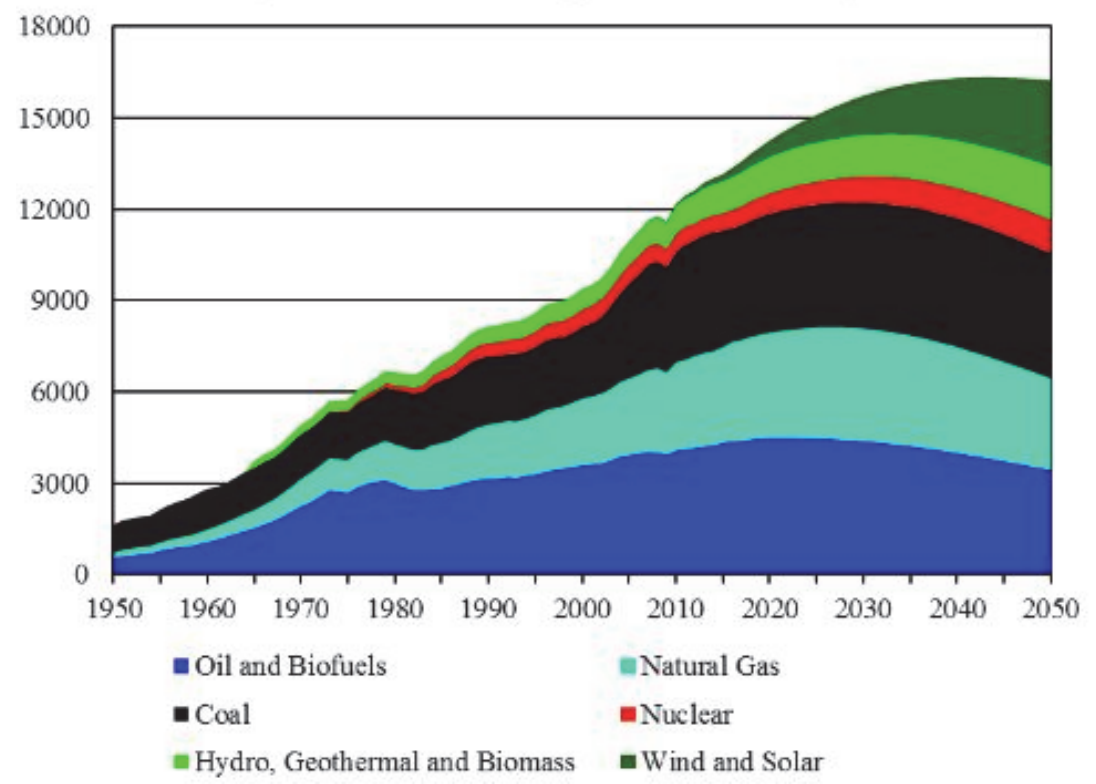

Figure 16. Energy consumption preedictions globally

Sources: World historical oil, natural gas, and coal consumption from 1950 to 1964 is assumed to be the same as production; world primary energy consumption and its composition from 1965 to 2015 is from BP (2016); world primary energy composition and its composition from 2016 to 2050 is base on this report's projections.

http://peakoilbarrel.com/world-energy-2016-2050-annual-report/

"What are we waiting for?", ask economist Stern (2015). Reply: G20 real action. The G20 group of nations is responsible for more than $3 / 3$ rds of the $\mathrm{CO} 2$ emissions. They do not face enormous transaction cost like the UNFCCC. They can act and not only make enquiries, like the IPCC. But they rely upon resilience: Let each country respond to climate change. Global warming leads to enormous externalities (Stern, 2007). It requires global policy responses, where only the G20 group can lead. They must pay for the costs they place upon others. It is in their own interests. But we have seen above that they have little readiness to fulfill the COP21 Treaty goals. The chaotic developments in climate change will be conducive to chaotic changes in social systems and economic activity, leading to massive people mobility. The COP project is not credible.

\section{References}

\section{Sources: Solar power}

Paris 2015: Tracking country climate pledges. Carbon Brief. Retrieved from https://www.carbonbrief.org/paris-2015-tracking-country-climate-pledges

Janssens-Maenhout, G., Crippa, M., Guizzardi, D., Muntean, M., Schaaf, E., Olivier, J.G.J., Peters, J.A.H.W., Schure, K.M.: Fossil CO2 and GHG emissions of all world countries, EUR 28766 EN,Publications Office of the European Union, Luxembourg, 2017, ISBN 978-92-79-73207-2, doi:10.2760/709792, JRC107877. World Bank Data Indicators. Retrieved from http://data.worldbank.org

CO2 Emission Reduction With Solar. Retrieved from http://www.solarmango.com/in/tools/solar-carbon-emission-reduction

EDGAR v 4.3.2, European Commission, Joint Research Centre (JRC)/PBL Netherlands Environmental Assessment Agency. Emission Database for Global Atmospheric Research (EDGAR), release version 4.3.2. Retrieved from http://edgar.jrc.ec.europe.eu, 2016 forthcoming

\section{GDP sources:}

OECD National Accounts data files

World Bank national accounts data. Retrieved from http://data.worldbank.org 


\section{GHG and energy sources:}

BP Energy Outlook 2016.

British Petroleum Statistical Review of World Energy 2016

Energy Information Administration. Washington, DC.

EU Emissions Database for Global Research EDGAR. Retrieved from http://edgar.jrc.ec.europa.eu/

EU Joint Research Centre Emission Database for Global Atmospheric Research. Retrieved from http://edgar.jrc.ec.europa.eu/overview.php

http://unfccc.int/ghg_data/ghg_data_unfccc/time_series_annex_i/items/3814.php

International Energy Agency. Paris.

UN Framework Convention on Climate Change. Retrieved from

World Bank Data Indicators. Retrieved from http://data.worldbank.org

World Resources Institute CAIT Climate Data Explorer. Retrieved from http://cait.wri.org

\section{Literature}

Asian Development Bank. (2015). Southeast Asia and the economics of global climate stabilization. Mandaluyong City, Philippines: Asian Development Bank,

Barro, R. J., \& Xavier, X. Sala-i-Martin (1992). Convergence. . Convergence. Journal of Political Economy, 100(2), 223-251. https://doi.org/10.1086/261816

Barro, R. J., \& Xavier, X. Sala-i-Martin (1995). Economic Growth. McGrow Hill.

Barro, R.J. (1991) Economic Growth in a Cross Section of Countries. The Quarterly Journal of Economics, 106(2), 407-443. https://doi.org/10.2307/2937943

Climate Science Special Report: Fourth National Climate Assessment_(USGCRP, 2017) Retrieved from https://assets.documentcloud.org/documents/4174364/Climate-Science-Special-Report-2017.pdf

Conka, K. (2015). Un Unfinished Foundation. The United Nations and Global Environmental Governance. Oxford: OUP.

Gleick, J. (1987) Chaos. New York: Viking books.

Kaya, Y., \& Yokoburi, K. (1997). Environment, energy, and economy: Strategies for sustainability. Tokyo: United Nations University Press.

Lorenz, E. N. (1969). Three approaches to atmospheric predictability. in Bulletin of the American Meteorological Society, 50, 345-349.

Myhre, G., Highwood, E. J., Shine, K. P., \& Stordal, F. (1998). New estimates of radiative forcing due to well mixed greenhouse gases. Geophysics Research Letters, 25(14), 2715-2718

Ostrom, E. (1990). Governing the Commons. Cambridge: Cambridge U.P.

Ramesh, J. (2015). Green Signals: Ecology, Growth and Democracy in India (2015). Oxford : Oxford University Press.

Rostow, W. W. (1960). The Stages of Economic Growth: A Non-Communist Manifesto. Cambridge: Cambridge University Press.

Sachs, J. D. (2015). The Age of Sustainable Development. New York: Columbia University Press.

Stern, N. (2007). The Economics of Climate Change. Oxford: OUP.

Stern, N. (2015). What are we waiting for? Cambridge, MA: MIT Press.

Vogler, J. (2016). Climate Change in World Politics. Basingstoke: MacmillanPalgrave

\section{Copyrights}

Copyright for this article is retained by the author(s), with first publication rights granted to the journal.

This is an open-access article distributed under the terms and conditions of the Creative Commons Attribution license (http://creativecommons.org/licenses/by/4.0/). 